\title{
Öğretmen Adaylarının Değer Tercihlerinin Öğretmenlik Mesleğine Yönelik Tutumlarına Etkisi ${ }^{1}$
}

\author{
Yrd. Doç. Dr. Ayşin AYDINAY SATAN \\ Marmara Üniversitesi, Atatürk Eğitim Fakültesi, Eğitim Bilimleri Bölümü, \\ Kadıköy / İstanbul / Türkiye
}

\section{Özet}

Bu araştırmanın amacı, eğitim fakültesinde öğrenim görmekte olan öğrencilerin değer tercihlerinin öğretmenlik mesleğine yönelik tutumlarına etkisinin incelenmesidir. Araştırmanın yönteminde ilişkisel tarama modeli kullanılmaktadır. Araştırmanın evrenini Marmara Üniversitesi Atatürk Eğitim Fakültesi'nde okuyan 4. sınıf öğrencileri oluşturmaktadır. Bu araştırma 2011-2012 eğitim ve öğretim y1lı içerisinde yapılmıştır. Araştırmanın örneklemini 9 bölüm ve bu bölümlerde okuyan toplam 328 öğrenci oluş̧urmaktadır. Araştırmada veriler Schwartz Değerler Listesi, Öğretmenlik Mesleğine Yönelik Tutum Ölçeği kullanılarak toplanmıştır. Araştırmada değerler listesinin alt boyutları ile öğretmenlik mesleğine yönelik tutum arasındaki korelasyon katsayıları 0.120 ile 0.324 olarak değişmektedir. Regresyon analizi sonuçlarına göre, değerler ölçeğine ait güvenlik, geleneksellik ve güç alt boyutları öğretmenlik

\footnotetext{
${ }^{1}$ Bu çalışma 16-18 Kasım 2012 tarihleri arasında İstanbul'da düzenlenen “II. Uluslararası Değerler ve Eğitimi Sempozyumu"nda sunulmuştur.

* Tel: +902163459090 E-posta: aysin.satan@marmara.edu.tr

(C) 2014 Kalem Eğitim ve Sağlık Hizmetleri Vakfı. Bütün Hakları Saklıdır.

ISSN: $2146-5606$
} 
mesleğine yönelik tutumları 0.19 düzeyinde açıklamaktadır.

Anahtar Kelimeler: Değerler; Değer sıralaması; Tutum; Öğretmen tutumlar1; Öğretmen.

\title{
The Impact of Value Preferences Of Preservice Teachers on Their Teaching Profession Attitudes
}

\begin{abstract}
The purpose of this study was to examine the effect of value preferences of university students attending a faculty of education on their attitudes towards teaching profession. Relational screening model was used in this study. The research universe consisted of $4^{\text {th }}$ grade students of Marmara University Ataturk Faculty of Education. The study was conducted in the 2011-2012 academic year. The research sample comprised of 9 departments and a total of 328 students from those departments. Research data were collected by means of Schwartz's List of Values, Attitude Scale Concerning Teaching Profession, and Personal Information Form. The coefficients of correlations between the sub-dimensions of the list of values and the attitudes towards teaching profession varied between -0.190 and 0.324 . The results of regression analysis demonstrated that the sub-dimensions of security, tradition, and power appearing in the values inventory explained the attitudes towards teaching profession by 0.19 .
\end{abstract}

Keywords: Values; Value ordering; Attitude; Teacher attitudes; Teacher.

\section{Extended Summary}

\section{Purpose}

This study made an attempt to answer the following questions in order to determine the effect of the value preferences of final year students attending a faculty of education in Turkey on their attitudes towards teaching profession: 
1. Is there any relationship between the individual value preferences of students and their attitudes towards teaching profession?

2. Do the individual value preferences of students vary significantly by gender?

3. Do the attitudes of students towards teaching profession vary significantly by gender?

4. Are the individual value preferences of students a significant predictor of their attitudes towards teaching profession?

\section{Method}

Relational screening model was used in this study. The research universe consisted of $4^{\text {th }}$ grade students of Marmara University Ataturk Faculty of Education. The research sample was determined via convenience sampling which is a selective sampling method, among from the $4^{\text {th }}$ grade students from the departments of Social Studies Teaching, English Language Teaching, Psychological Counseling and Guidance Teaching, Science Teaching, French Language Teaching, Art Teaching, Mathematics Teaching, and Computer and Educational Technologies Teaching at Ataturk Faculty of Education.

According to the demographic data obtained from the sample, a total of 328 students participated in the study. Of these students, 205 $(62.5 \%)$ were female, and $123(37.5 \%)$ were male. "Attitude Scale Concerning Teaching Profession" and "Schwartz's List of Values" were employed in this study.

The Pearson product-moment correlation coefficients were cal- 
culated in order to see the relationship between the sub-dimensions of the list of individual value preferences and the scores related to attitudes towards teaching profession. T-test analysis was carried out in order to determine whether individual value preferences and the attitudes towards teaching profession varied by gender. Multiple regression analysis was performed in order to determine the capacity of values for explaining and predicting the attitudes towards teaching profession.

\section{Result}

The correlation coefficients calculated for attitude scale concerning teaching profession varied between .120 and .366. A low level positive and significant relationship was found between the sub-dimensions of the scale of the list of values and scores related to attitudes towards teaching profession [Universalism $(\mathrm{r}=.303, \mathrm{p}<.01)$, Conformity $(\mathrm{r}=.310, \mathrm{p}<.01)$, Benevolence $(\mathrm{r}=.347, \mathrm{p}<.01)$, Tradition $(\mathrm{r}=.309, \mathrm{p}<.01)$, Security $(\mathrm{r}=.366, \mathrm{p}<.01)$, Stimulation $(\mathrm{r}=120 \mathrm{p}<.05)$, Achievement $(r=.238, \mathrm{p}<.01)$, Self-Direction $(r=.210 \mathrm{p}<.01)$, Hedonism $(r=.172, p<.01)$, Power $(r=.317, p<.01)]$. While the "hedonism" sub-dimension of the individual value preferences of the participants varied significantly by gender $[\mathrm{t}(326)=.4 .229, \mathrm{p}<.01]$, no significant variation was observed in other sub-dimensions. Male students had a more positive hedonism value $(\bar{X}=21.112)$ in comparison to female students $(\bar{X}=20.861)$. In addition, the attitudes of students towards teaching profession varied significantly by gender $[\mathrm{t}(326)=.036$, $\mathrm{p}<.01]$. Female students had more positive attitudes towards teaching 
profession $(\bar{X}=133.09)$ in comparison to male students $(\bar{X}=124.07)$. Finally, the variables of individual value preference (universalism, conformity, benevolence, tradition, security, stimulation, achievement, self-direction, hedonism, power) displayed a low level significant relationship with the attitudes towards teaching profession $(\mathrm{R}=.433$, $\left.\mathrm{R}^{2}=.188, \mathrm{p}<01\right)$. According to the standardized regression coefficients $(\beta)$, the relative order of importance of predictor variables for the attitudes towards teaching profession is as follows: security, power, and tradition. The examination of the results of t-test concerning the significance of regression coefficients demonstrates that the sub-dimensions of security, power and tradition are significant predictors of the attitudes towards teaching profession. Other sub-dimensions of the scale of list of values do not have any significant effect. The regression equation concerning the prediction of scores related to attitudes towards teaching profession is given below based on the multiple regression analysis conducted.

\section{Discussion}

Research findings show that there is a low level positive relationship between the attitudes of pre-service teachers towards teaching profession and the sub-dimensions of individual value preferences (i.e. security, hedonism, achievement, power, tradition, conformity, universalism, self-direction, benevolence and stimulation,). Male pre-service teachers gives more importance to the value of "Hedonism" in comparison to female pre-service teachers. Female pre-service teachers have higher scores related to attitudes towards teaching pro- 
fession in comparison to male pre-service teachers. The sub-dimensions of security, power and tradition (among the individual value preferences of pre-service teachers) are significant predictors of the attitudes towards teaching profession.

\section{Conclusion}

The studies aimed at enriching the value preferences or perceptions of pre-service teachers and raising awareness in this matter may enrich their positive attitudes towards teaching profession

\section{Giriş}

Günümüzde öğretmen yetiştirmede nicelik sorunları aşılmaya çalışılırken, nitelik sorunları da önemli görülmeye başlanmıştır (Dursunoğlu, 2003). Bu düşünceyi, son yıllarda öğretmenlerin yetiştirilmesi ve niteliklerinin artırılması konusunda yapılan araştırmalar, (Terzi ve Tezci, 2007; Yaşar, Gültekin, Türkan, Yıldız ve Girmen, 2005; Gözütok, Akgün ve Karacaoğlu, 2005) ve öğretmenlerin istenilen niteliklere sahip olmadıklarına ilişkin yaygın kanı (Üstüner, 2004; Taşdemir, 1996) desteklemektedir.

Öğretmen niteliklerine yönelik yapılan birçok araştırmada öğretmenlerin kişilik özellikleri, değerleri, davranışları, tutumları, ilgileri ve akademik özellikleri öğretme ve öğrenme sürecinde önemle vurgulanmaktadır (Erdem, Gezer ve Çokadar, 2005; Memişoğlu, 2006). Öğretmen nitelikleri ile ilgili araştırmalarda son y1llarda özellikle değerler, değer tercihleri ve değer eğitimi konuları ele alınmaktadır (Akkiprik, 2007; Aktepe ve Yel, 2009; İşcan ve Senemoğlu, 2009; Sarı, 
2005; Sezgin, 2006; Taşdan, 2010; Yiğittir ve Öcal, 2010). Öğretmen eğitiminde bireysel ve mesleki değerlerin kazandırılması önemli bir unsur olarak görülmektedir.

Değer kavramı ile ilgili olarak yapılan tanımlara baktığımızda, değer, bireyin ya da diğer toplumsal oluşumların yaşamına yol gösterici ilkeler olarak hizmet eden, önemlilikleri farklılık gösteren, arzu edilen amaçlardır (Schwartz, 1992). Rokeach (1973) ve Güngör (1998) değer kavramını, kişisel ve toplumsal olarak belirgin bir davranış biçimine veya yaşam amacına ilişkin sürekli arzu edilebilir veya edilemez olduğu hakkındaki inanç olarak tanımlamışlardır.

Güngör'e $(1998,2000)$ göre psikolojide değerin önemi, objektif bir esasa dayanıp dayanmamasında değil, insan davranışlarının yol göstericisi olarak oynadığı role bağlı olmasıdır. Değerler arasında bir üstünlük-öncelik ilişkisi bulunmaktadır. Bireyin değer sıralamasının birinci veya en üst sırasında bulunan değer, onun temel değeri sayılabilir. Değerler, insanın bilişsel yapısının başlıca unsurlarıdır. Değerler arasında da yüksek düzeyde bir uyumun olması, ortaya çıkacak uyuşmazlıkların hemen giderilmesi için zorunludur. Belli bir davranışın birden fazla değer ile uyumlu bir ilişki içinde olması beklenir.

Schwart, değerlerin motivasyonel amaç çeşitlerinin bir yansıması olduğunu belirtmekle birlikte, kavramsal bir tanım da geliştirmişlerdir. Buna göre değerler:

a. Fikir veya inançlardır.

b. Amaç ve davranışlarla iliş̧ilidirler. 
c. Durum ötesidir.

d. Davranış ve olayların seçim ve değişimine rehberlik ederler.

e. Taşıdıkları öneme göre sıralanırlar. Schwartz değerler üzerine temellenen modelinde motivasyonel olarak 10 değer tipi belirlemektedir. Bu 10 tip, dünya kültürlerinde kabul edilen temel değerlerin geniş bir dağılımını kapsar ve 10 değer tipi arasındaki ilişkilerin evrensele yakın bir yapısını tanzim eder. Bu 10 değer güç, başarı, hazcılık, uyar1lım, özyönelim, evrenselcilik, iyilikseverlik, gelenek, uyum ve güvenlik olarak belirlenmiştir (Schwartz, 1992; akt: Mehmedoğlu, 2007). Değer tipleri ve bunların altında yer alan değerler Tablo 1'de gösterilmiştir (Schwartz,1992; akt: Ünal, Deniz, Can, 2008).

Tablo 1. Değer Boyutları ve Tanımları 
Tanım

Güç: Sosyal statü, prestij, insanlar ve kaynaklar üzerine hâkimiyet veya kontrol kurmaktır.

Başarı: Sosyal standartlara göre gösterilen kişisel başarıdır.

Hazcılık (Hedonizim):Zevk ve hayatı sevmekle ilgili bir değerdir.

Uyarılım: Hayatta heyecan, değişiklik ve rekabet aramakla ilgili olan değerdir.

Kendini yönlendirme: Bu değer seçimde, düşüncede ve araştırmada yani düşünce ve eylemde bağımsızlığı içerir.

Evrensellik: İnsanlığın ve doğanın refahını korumayı, kabul etmeyi ve anlamayı açıklayan bir değerdir.

\section{Örnek değerler}

Otorite, toplumsal itibarı koruma, sosyal

Hırslı, yetenekli, başarılı ve etkili

Neşeli, hayattan zevk alan, kendini şımartan ve haz değerleri

Heyecanlı bir hayat, cüretkâr ve hayattaki çeşitlilik

Yaratıcılık, özgürlük, bağımsız, kendi hedeflerini seçen ve meraklı

Barış içerisinde bir dünya, açık fikirli, güzel bir dünya, eşitlik, çevreyi koruyan, sosyal adalet, doğa ile bütünlük ve erdem

Yardımseverlik: Kişisel ilişki kurulan insanların refahını düşünmekle ilgili bir değer boyutudur. Geleneksellik: Kişinin kültürü, dini ve geleDürüst, sadık, sorumluluk sahibi, affedici ve yardımsever neklerine saygısını ortaya koyan bir değer Hayattaki yerini kabul eden, dindar, alçakgönüllü, ılımlı ve geleneklere boyutudur. saygil1

Uyumluluk: Diğerlerine zarar veren sosyal Büyüklerine sayg1 gösteren, itaatbeklenti ve normları çiğneyen istek, faaliyet ve kâr, nezaket ve özdisiplin hisleri kontrol altına almakla ilgili olan değer boyutudur.

Güvenlik: Kişinin toplumla olan ilişkilerinde Temiz, aile güvenliği, ulusal güuyum ve güvenliği içeren değer boyutudur. venlik, karşılıklı iyilik ve sosyal düzen

$\mathrm{Bu} 10$ değer tipi ayrıca, farklı motivasyonel hedefler arasında karşılıklı uygunluk ve zıtlık esasına göre 2 boyutta gruplandırılmıştır. Uygun motivasyonel amaçları paylaşan değer tipleri son derece pozitif olarak ilişkilendirilmiş ve biri diğeri ile bitişik; çatışan motivasyonel hedeflerle karakterize edilmiş olan değer tipleri ise düşük veya daha negatif olarak ilişkilendirilmiş ve biri diğerine zıt olarak konumlandırrlmıştır. Bu iki boyuttan; ilki, Yeniliğe/Değişime açıklık (özyönelim ve 
uyarılım değerler tipleri) X Muhafazakarlık (güvenlik, uyma ve gele-

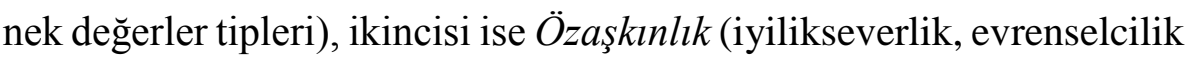
değer tipleri) X Özgenişletim (güç ve başarı değer tipleri) dir.

Değerlere yönelik olarak sürdürülen çalışmalarda farklı sınıflandırmalardan biri de Rokeach tarafından yapılan değer sınıflandırmalarıdır. Rokeach yaptığı sınıflandırma da amaç değerler (başarı, özgür seçim, eşitlik, erdem vb) ve bu değerlerin elde edilmesinde gerekli görülen araç değerler (cesaret, sorumluluk, gerçeklik, tutku vb) olarak iki düzeyde ele almıştır. Bu sınıflandırmaların da temel alındığı birçok çalışmada değerler, toplumsal, bireysel ve örgütsel açıdan incelenmiştir (Kuşdil ve Kağıtçıbaşı, 2000).

Bireylerin, grupların ve kültürlerin değerleri hakkında bilgi sahibi olmak onların tutum ve davranışlarına ilişkin kestirimlerde bulunmamıza yardımcı olabilir. Değerlerin bireyin sergilediği davranış ve tutumlar üzerinde kalıcı etkilerinin olduğuna inanılmaktadır. İçselleştirilen ve genel kabul gören değerler gelecek kuşaklara aktarılır. Değerlerin gelecek kuşaklara aktarılmasında etkili olan unsurlardan birisi de öğretmenlerdir (Başaran, 1994; Locke, 1983; Rokeach, 1973). Öğretmenlerin içinde bulunduğu okul ve çevrenin değerleri ile uyumlu tutum ve davranış içersinde olmaları gerekir (Bursalığlu, 2000).

Öğretmen adaylarının olumlu ve yüksek düzeyde öğretmenlik tutumları geliştirmelerinin birçok değişkene bağlı olduğu belirtilmekte ve bu değişkenler içersinde değerler sistemine dikkat çekilmektedir (Şenel Demir, Sertelin, Kılıçaslan ve Köksal, 2004). Bu bağlamda 
değerlerden yola çıkarak tutumlara ulaşmak daha güvenilir ve daha geçerli bir yol olarak görülmektedir (Güvenç, 1976). Olumlu tutumlar kazanmış öğretmen adayları demek nitelikli öğretmenler demektir. Öğretmenlerin mesleklerine karşı tutumları, davranışlarına ve sınıf atmosferine yansıyarak öğrencilerinin kişilik geliştirmelerinde, öğretmen öğrenci ilişkilerinin niteliğinde ve öğrenmenin sağlanmasında belirgin bir rol oynamaktadır (Semerci ve Semerci, 2004). Bu nedenle öğretmen tutumlarının olumlu yönde olması beklenilir.

$\mathrm{Bu}$ görüş açısından bakıldığında eğitim fakültelerinin ortak amacı, etkili ve nitelikli öğretmen yetiştirmektir. Öğretmen yetiştiren yükseköğretim kurumlarında öğretmen adaylarına, bilgi ve beceri kazandırmanın yanında öğretmenliğin gerektirdiği uygun tutum ve davranışları kazandırıcı yaklaşımlara yer verilmesi son derece önemlidir (Oktay, 1991). Bu açıdan öğretmen adaylarının mesleğe yönelik tutumlarını belirleme, biçimlendirme ve yönlendirmede değerlerin önemli rol oynadığı düşünülmektedir.

Bu çalışma, Marmara Üniversitesi Atatürk Eğitim Fakültesi’nde okuyan son sınıf öğrencilerinin değer tercihlerinin öğretmenlik mesleğine yönelik tutumlarına etkisini belirlemek amacıyla aşağıdaki sorulara cevap aranmıştır.

1. Öğrencilerin bireysel değer tercihleri ile öğretmenlik mesleğine yönelik tutum arasında bir ilişki var mıdır?

2. Öğrencilerin bireysel değer tercihleri cinsiyete göre anlamlı bir farkl111k göstermekte midir? 
3. Öğrencilerin öğretmenlik mesleğine yönelik tutumlar cinsiyete göre anlamlı bir farklılık göstermekte midir?

4. Öğrencilerin bireysel değer tercihleri öğretmenlik mesleğine yönelik tutumun anlamlı bir yordayıcısı mıdır?

\section{Yöntem}

\section{Evren ve Örneklem}

Araştırmanın yönteminde ilişkisel tarama modeli kullanılmıştır. Araştırmanın evrenini Marmara Üniversitesi Atatürk Eğitim Fakültesi’ne devam eden 4. sınıf öğrencileri oluşturmuştur. Araştırmanın örneklemi Atatürk Eğitim Fakültesinin Sosyal Bilgiler Öğretmenliği, İngilizce Öğretmenliği, Psikolojik Danışmanlık ve Rehberlik Öğretmenliği, Fen Bilgisi Öğretmenliği, Fransızca Öğretmenliği, Resim Öğretmenliği, Matematik Öğretmenliği ve Bilgisayar ve Öğretimi Teknolojileri Eğitimi Öğretmenliği bölümlerine devam eden 4. sınıf öğrencilerin seçkili örneklem alma yollarından olan Uygunluk Örneklemi yoluyla tespit edilmiştir. Uygunluk örnekleminde araştırmacı çalışması için elverişli bir şekilde ulaşabileceği grubu belirler ve araştırma verileri o gruptan toplanır. Temel özelliği araştırmacının örnekleme ulaşmasının kolay olmasıdır (Fraenkel ve Wallen, 1993).

Örneklemden elde edilen demografik verilere bakıldığında, toplam 328 öğrenci bulunmaktadır. Bu öğrencilerin 205’i (\% 62.5) kız, 123 'ü (\% 37.5) erkektir. Öğrencilerin 20'si (\% 6.1) Resim Öğretmenliği, 27'si (\% 8.2) İlköğretim Matematik Öğretmenliği, 33’ü (\% 10.1) Sosyal Bilgiler Öğretmenliği, 75'i (\% 22.9) Psikolojik Danışmanlık ve Rehberlik Öğretmenliği, 49’u (\% 14.9) Fen Bilgisi Öğretmenliği, 25’i 
(\% 7.6) Müzik Öğretmenliği, 25’i (\% 7.6) İngilizce Öğretmenliği, 38'i

(\% 11.6) Fransızca Öğretmenliği ve 36’sı (\% 11.0) Bilgisayar ve Öğretimi Teknolojileri Eğitimi Öğretmenliği bölümlerinin dördüncü sınıf öğrencilerinden oluşmaktadır.

\section{Veri Toplama Araçları}

Araştırmada öğretmenlik mesleğine yönelik tutumlarını ölçmek için Özgür (1994) tarafından geliştirilen “Öğretmenlik Mesleğine Yönelik Tutum Ölçeği” ve Schwartz (1999) tarafından geliştirilen "Schwartz Değerler Listesi” kullanılmıştır.

Özgür (1994) tarafından geliştirilen ölçek 5'li Likert tipi ölçme arac1 olup, yirmisi olumlu, on üçü olumsuz $(3,5,11,12,14,20,23,26$, 27, 28, 29, 31, 32) toplam otuz üç maddeden oluşmaktadır. Ölçek; Hiç Katılmıyorum:1, Çok Az Katılıyorum:2, Biraz Katılıyorum:3, Oldukça Katılıyorum:4, Tamamen Katılıyorum:5 şeklinde puanlandırılmıştır. Olumsuz maddeler ise tersten puanlandırılmıştır. Ölçekten alınacak puanın yüksek ya da düşük olması, ölçek ile ölçülen özelliğin katılımcıda yüksek ya da düşük olduğunu gösterir. Ölçeğin sıra farkı korelasyon katsayısı hesaplanarak ilişki katsayısı 0.63 bulunmuştur. $\mathrm{Bu}$ araştırmada ise ölçeğin güvenirlik katsayısı 0.92 olarak bulunmuştur. Ölçeğin orijinal formunun tek boyutlu olarak geliştirilmiş olması da göz önünde bulundurularak, ölçek üzerinde boyutlandırmaya gitmeden toplam öğretmenlik mesleğine yönelik tutum puanı hesaplanmıştır.

Araştırmada değer yönelimlerini ölçmek için 57 değerden oluşan "Schwartz Değerler Listesi” kullanılmıştır. Katılımcılar toplam 57 
değeri ve yanlarında parantez içinde verilmiş olan açıklamaları okuduktan sonra her birini kendi hayatlarını yönlendiren bir ilke olmaları açısından taşıdıkları öneme göre -1 (ilkelerime ters düşer) ile 7 (en üst düzeyde önemlidir) arasında değişen bir ölçek üzerinde değerlendirmektedirler. Ölçek on alt boyuttan oluşmaktadır. Kuşdil ve Kağıtçıbaşı (2000) tarafından yapılan çalışmada ana boyut ve değer tipleri ile her bir değer tipi içerisinde yer alan değerlerle ilgili olarak kullanılan Türkçe adlandırmalar esas alınmıştır. Özaşkınlık değer boyutu evrenselcilik (universalizm) ve iyilikseverlik (benevolence), özgenişletim değer boyutu ise başarı (achievement), güç (power) ve hazcılık (hedonizm) değer tiplerini kapsamaktadır. Kuşdil ve Kağıtçıbaşı (2000) tarafından yapılan çalışmada değerler için Cronbach Alpha ile hesaplanan iç tutarlılık katsayılarının .51-.77, değer grupları için .77-.83 arasında değiştiği görülmüştür. İç tutarlılık katsayıları evrenselcilik için .77, iyilikseverlik için .76, hazcılık için .54, güç için .75, başarı için .66, uyarılma .70, özyönelim .69, geleneksellik .63, uyma .51, güvenlik için .59 olarak bulunmuştur. Ayrıca ana değer grupları iç tutarlılık analiz sonuçlarına baktığımızda; muhafazakârlık grubu için .80, yeniliğe açıklık değer grubu için .81, özaşkınlık değer grubu için .81, özgenişletim değer grubu için .84 hesaplanmıştır.

\section{Veri Analizi}

Bireysel değerler tercihi listesinin alt boyutları ile öğretmenlik mesleğine yönelik tutum puanları arasındaki ilişkiyi görmek için Pearson Momentler Çarpımı Korelasyon katsayıları hesaplanmıştır. Cinsiyete göre bireysel değerler tercihleri ve öğretmenlik mesleğine yöne- 
lik tutumları farklılaşıp farklılaşmadığını bulmak için $t$ testi analizi yapılmıştır. Değerlerin, öğretmenlik mesleğine yönelik tutumları açıklama ve yordama gücünün belirlenmesinde çoklu regresyon analizi uygulanmıştır. Elde edilen veriler "SPSS for windows 11.0" programında değerlendirilmiştir.

\section{Bulgular}

Tablo 2. Öğretmenlik Mesleğine Yönelik Tutum Puanları İle Değerler Listesi Ölçeği Alt Boyut Puanlarına Ait Pearson Momentler Çarpımı Korelâsyon Katsayıları

\begin{tabular}{llc}
\hline & & $\begin{array}{c}\text { Öğretmen Mesleğine } \\
\text { Yönelik Tutum }\end{array}$ \\
\hline \multirow{2}{*}{ Değerler Listesi } & Evrensel Düşünce & $.303^{* *}$ \\
& Uyumluluk & $.310^{* *}$ \\
& Yardımseverlik & $.347^{* *}$ \\
& Geleneksellik & $.309^{* *}$ \\
& Güvenlik & $.366^{* *}$ \\
& Uyarılım & $.120^{*}$ \\
Başarı & $.328^{* *}$ \\
& Öz Yönelim & $.210^{* *}$ \\
& Hazcılık & $.172^{* *}$ \\
Güç & $.317^{* *}$ \\
\hline
\end{tabular}

$\mathrm{p}<.001^{* *}, \mathrm{p}<.05^{*}$

Tablo 2'deki korelasyon katsayıları incelendiğinde, değerler listesi ölçeği ile Öğretmenlik mesleğine yönelik tutum ölçeği için hesaplanan korelasyon katsayılarının 0.120 ile 0.366 arasında değiştiği görülmektedir. Tablo 2'nin incelenmesinde, değer listesi ölçeğinin 10 alt boyutu ile öğretmen mesleğine yönelik tutum puanları arasında zayıf düzeyde pozitif ve anlamlı bir ilişki olduğu görülmektedir güvenlik 
$(\mathrm{r}=.366, \mathrm{p}<.01)$, yardımseverlik $(\mathrm{r}=.347, \mathrm{p}<.01)$, başarı $(\mathrm{r}=.328, \mathrm{p}<.01)$, güç $(\mathrm{r}=.317, \mathrm{p}<.01)$, geleneksellik $(\mathrm{r}=.309, \mathrm{p}<.01)$, uyumluluk $(\mathrm{r}=.310$, $\mathrm{p}<.01)$, evrensel düşünce $(\mathrm{r}=.303, \mathrm{p}<.01)$, öz yönelim $(\mathrm{r}=.210, \mathrm{p}<.01)$, hazc1lik $(\mathrm{r}=.172, \mathrm{p}<.01)$ ve uyar1lım $(\mathrm{r}=120, \mathrm{p}<.05)$. Korelasyon katsayıları ayrıntılı olarak incelendiğinde değerler listesi ölçeğinin ilk sırasında yer alan güvenlik, yardımseverlik, başarı, güç ve geleneksellik değerlerinin öğretmenlik mesleğine yönelik tutumla arasındaki ilişkinin diğer 5 alt değere göre daha yüksek olduğu görülmektedir.

Tablo 3. Öğrencilerin Bireysel Değer Tercihlerinin Cinsiyete Göre Farklılaşıp Farklılaşmadığını Belirlemek Üzere Yapılan Bağımsız Grup t Testi Sonuçları

\begin{tabular}{|c|c|c|c|c|c|c|c|}
\hline & Cinsiyet & $\mathbf{N}$ & $\overline{\mathrm{X}}$ & Ss & Sd & $\mathbf{T}$ & $\mathbf{p}$ \\
\hline Evrensel & $\mathrm{K} 1 \mathrm{z}$ & 205 & 13.804 & 5.101 & \multirow{2}{*}{326} & \multirow{2}{*}{.989} & \multirow{2}{*}{.323} \\
\hline Düşünce & Erkek & 123 & 13.634 & 5.747 & & & \\
\hline \multirow{2}{*}{ Uyumluluk } & Kiz & 205 & 18.297 & 5.358 & \multirow{2}{*}{326} & \multirow{2}{*}{.446 } & \multirow{2}{*}{.656} \\
\hline & Erkek & 123 & 15.561 & 6.165 & & & \\
\hline \multirow{2}{*}{ Yardımseverlik } & $\mathrm{K} 1 \mathrm{z}$ & 205 & 27.346 & 5.067 & \multirow{2}{*}{326} & \multirow{2}{*}{.622} & \multirow{2}{*}{.534} \\
\hline & Erkek & 123 & 26.260 & 5.337 & & & \\
\hline \multirow{2}{*}{ Geleneksellik } & Kiz & 205 & 19.346 & 4.702 & \multirow{2}{*}{326} & \multirow{2}{*}{-1.074} & \multirow{2}{*}{.284} \\
\hline & Erkek & 123 & 19.040 & 5.690 & & & \\
\hline \multirow{2}{*}{ Güvenlik } & Kiz & 205 & 12.809 & 4.498 & \multirow{2}{*}{326} & \multirow{2}{*}{1.447} & \multirow{2}{*}{.149} \\
\hline & Erkek & 123 & 13.122 & 4.447 & & & \\
\hline \multirow{2}{*}{ Uyarılım } & Kiz & 205 & 28.131 & 5.778 & \multirow{2}{*}{326} & \multirow{2}{*}{-.631} & \multirow{2}{*}{.542} \\
\hline & Erkek & 123 & 27.138 & 6.398 & & & \\
\hline \multirow{2}{*}{ Başarı } & Kiz & 205 & 21.370 & 7.179 & \multirow{2}{*}{326} & \multirow{2}{*}{.526} & \multirow{2}{*}{.599} \\
\hline & Erkek & 123 & 22.235 & 6.861 & & & \\
\hline \multirow{2}{*}{ Öz Yönelim } & Kiz & 205 & 27.419 & 5.589 & \multirow{2}{*}{326} & \multirow{2}{*}{1.842} & \multirow{2}{*}{.066} \\
\hline & Erkek & 123 & 27.008 & 6.126 & & & \\
\hline \multirow{2}{*}{ Hazcilık } & Kız & 205 & 20.861 & 4.799 & \multirow{2}{*}{326} & \multirow{2}{*}{4.229} & \multirow{2}{*}{$.00 * *$} \\
\hline & Erkek & 123 & 21.112 & 5.113 & & & \\
\hline Güc & Kiz & 205 & 44.682 & 8.454 & 326 & .289 & .780 \\
\hline & Erkek & 123 & 43.731 & 8.399 & & & \\
\hline
\end{tabular}


Tablo 3'de araştırmaya katılan öğrencilerin bireysel değerler tercihinin "hazcilık" alt boyutu cinsiyete göre anlamlı bir farklılık gösterirken $[\mathrm{t}(326)=.4 .229, \mathrm{p}<.01]$ diğer alt boyutlarda anlamlı bir farkl11ık göstermemektedir. Erkek öğrencilerin hazcılık değeri ( $\bar{X}=21.112), \mathrm{k} 1 \mathrm{z}$ öğrencilere $(\bar{X}=20.861)$ göre daha olumludur. $\mathrm{Bu}$ bulgu, erkek öğrencilerin hazcılık değerine daha fazla önem verdikleri şeklinde yorumlanabilir.

Tablo 4. Öğretmenlik Mesleğine Yönelik Tutum Puanının Cinsiyet Değişkenine Göre Farklılaşıp Farklılaşmadığını Belirlemek Üzere Yapılan Bağımsız Grup t Testi Sonuçları

\begin{tabular}{lcccccc}
\hline Cinsiyet & $\mathbf{N}$ & $\overline{\mathrm{X}}$ & $\mathbf{S}$ & $\mathbf{S d}$ & $\mathbf{T}$ & $\mathbf{p}$ \\
\hline K1z & 205 & 133.09 & 17.009 & 326 & .036 & .000 \\
Erkek & 123 & 124.07 & 20.201 & & & \\
\hline $\mathrm{P}<.001 * *, \mathrm{P}<.05^{*}$ & & & & &
\end{tabular}

Tablo 4'de araştırmaya katılan öğrencilerin öğretmenlik mesleğine yönelik tutumları cinsiyete göre anlamlı bir farklılık göstermektedir $[\mathrm{t}(326)=.036, \mathrm{p}<.01] . \mathrm{K} 1 \mathrm{z}$ öğrencilerin öğretmenlik mesleğine yönelik tutumları $(\bar{X}=133.09)$, erkek öğrencilere $(\bar{X}=124$. 07) göre daha olumludur.

Tablo 5. Öğretmenlik Mesleğine Yönelik Tutumun Yordanmasına İlişkin Çoklu Regrasyon Analizi Sonuçları 


\begin{tabular}{lccccc}
\hline Değişken & $\begin{array}{c}\text { Standardize } \\
\text { Edilmemiş } \\
\text { Beta }\end{array}$ & $\begin{array}{c}\text { Std } \\
\text { Hata }\end{array}$ & $\begin{array}{c}\text { Standardize } \\
\text { Edilmiş } \\
\text { Beta }(\boldsymbol{\beta})\end{array}$ & T & P \\
\hline SABİT & 88.058 & 5.983 & & & \\
Evrensel Düşünce & .144 & .179 & .065 & .806 & .421 \\
Uyumluluk & -.164 & .336 & -.043 & -.486 & .627 \\
Yardımseverlik & .353 & .286 & .109 & 1.235 & .218 \\
Geleneksellik & .359 & .178 & .135 & 2.011 & $.045^{*}$ \\
Güvenlik & .670 & .243 & .215 & 2.649 & $.008^{*}$ \\
Uyarılım & -.171 & .300 & -.041 & -.571 & .569 \\
Başarı & .444 & .238 & .120 & 1.863 & .063 \\
Öz Yönelim. & -.166 & .282 & -.046 & -.587 & .558 \\
Hazc1lk & .307 & .212 & .095 & 1.446 & .149 \\
Güç & -.475 & .212 & -.135 & -.240 & $.026^{*}$ \\
\hline R=.433 R $\mathrm{R}^{2=.188}$ & $\mathrm{~F}(9,225)=6.644$ & $\mathrm{p}<.05^{*}$ & & &
\end{tabular}

Tablo 5'te görüldüğü üzere bireysel değer tercihi (evrensel düşünce, uyumluluk, yardımseverlik, geleneksellik, güvenlik, uyarılım, başarı, kendini yönetme, hazcılık, güç) değişkenleri öğretmenlik mesleğine yönelik tutum ile zayıf düzeyde anlamlı bir ilişki vermektedir $\left(\mathrm{R}=.433, \mathrm{R}^{2}=.188, \mathrm{p}<01\right)$. Standardize edilmiş regresyon katsayısı $(\beta)$ göre, yordayıcı değişkenlerinin öğretmenlik mesleğine yönelik tutum üzerindeki göreli önem sırası; güvenlik, geleneksellik ve güç alt boyutlarıdır. Regresyon katsayılarının anlamlılığına ilişkin t-testi sonuçları incelendiğinde ise güvenlik, geleneksellik ve güç alt boyutlarının öğretmenlik mesleğine yönelik tutum üzerinde önemli (anlamlı) bir yordayıcı olduğu görülmektedir. Değerler listesi ölçeğinin diğer alt boyutları ise önemli bir etkiye sahip değildir. Yapılan çoklu regresyon 
analizine göre, öğretmen mesleğine yönelik tutum puanlarının yordanmasına ilişkin regresyon denklemi aşağıda verilmiştir:

$\mathrm{Y}=88.058+.670 *($ Güvenlik $)+.135 *($ Geleneksellik $)+(-.475) *(\mathrm{Güç})+.4$ 44(Başarı)+ .307(Hazcılık)+.353 (Yardımseverlik)- .166 (Özyönelim).171 (Uyarılım)-.164(Uyumluluk)

\section{Tartışma, Sonuç ve Öneriler}

Araştırmada Değerler listesi ölçeğinin 10 alt boyutu ile öğretmenlik mesleğine yönelik tutum puanları arasında pozitif ve zayıf düzeyde anlamlı bir ilişki bulunmuştur. Öğretmen adaylarının bireysel değer tercihlerinin öğretmenlik mesleğine yönelik tutum ile olan ilişkisi şu şekilde sıralanmaktadır; güvenlik, yardımseverlik, başarı, güç, geleneksellik, uyumluluk, evrensellik, öz yönelim, hazcllı ve uyartlımdır. Alanyazında öğretmen adaylarının bireysel değer tercihleri ile öğretmelik mesleğine yönelik tutumunu birlikte analiz eden araştırma sonucuna rastlanmamaktadır. Ancak bazı araştırmaların öğretmen adaylarının ve öğretmenlerin önem sırasına göre öncelik verdikleri bireysel değer tercihleri ile ilgili sonuçlar, araştırmadan elde edilen bu bulguyu dolaylı da olsa desteklemektedir (Yıldız, Taşkıran ve Çiçek, 2011; Özkul, 2007; Alnıaçık ve Yılmaz, 2008; Sezgin, 2006; Aktepe ve Yel, 2009; Aydın, 2003).

Schwartz'ın değer kuramında yapıları gereği güvenlik, yardımseverlik, başarı, güç, geleneksellik, uyumluluk, evrensellik alt boyutlar1 güdüsel olarak birbirleriyle uyumluluk göstermektedir. Araştırmada uyumluluk gösteren değerlere baktığımızda güvenlik, yardımseverlik, 
geleneksellik, uyumluluk ve evrensellik yer almaktadır. Güvenliğin güdüsel amacı emniyet, uyum ve toplum, ilişkilerin ve kişinin kendi benliğinin istikrarının devamının sağlanmasıdır. Yardımseverlik, yakın çevredeki diğer insanların refahına odaklanırken, geleneksel değeri oluşturan güdü, saygı, bağlılık kültür ya da din tarafından bireye yüklenen gelenek ve fikirlerin kabullenilmesidir. Uyumluluk değerinin güdüsü ise, başkalarını üzecek ya da zarar verecek, sosyal beklentileri ya da kuralları bozacak hareketlerin, isteklerin, dürtülerin sınırlanması oluşturur. Evrensellik ise, bütün insanların ve doğanın refahının anlaş1lmasına, değer kazanmasına ve korunmasına odaklanır. Bu değerler motivasyonel kaynakları dikkate alındığında muhafazakâr yaklaşım boyutunu yansıtmakta, insanların bencil duygularını aşmasına ve diğer insanların refahının artmasına yardımcı olmak şeklinde açıklanmaktadır (Schwartz, 1992; akt: Ünal, Deniz, Can, 2008). Schwartz’ın değer kuramına göre birbirine yakın olan değerlerin aynı güdüsel ihtiyaçları paylaşan birbirleri ile uyumlu değer tipleri olduğu belirtilmektedir. Ancak başarı ve güç değerleri yukarıda sözü edilen değerlere göre zıtlık göstermekle birlikte kendi aralarında uyumluluk da göstermektedir. Başarı değerinin amac1; kişisel yeterliliği göstermek doğrultusunda kişisel başarı iken, güç değerinin motivasyon aracı sosyal statü, prestij ve diğer insanları ve kaynakları kontrol etme isteği bulunmaktadır. Son üç değer öz yönelim,hazcılık ve uyarılımın, insanları kendi kişisel ilgilerini geliştirmeye motive eden değerlerdir. $\mathrm{Bu}$ değerlerin motivasyonel kaynaklarına baktığımızda ise kendini yönlendirme bireyin kendisini kontrol etmesi, özerklik ve bağımsızlığını yansıtan değerler olduğu görülmektedir. Öğretmen adaylarının değer tercih 
sıralamalarında farklılıklar değerlerin değişime açık yapılar olduğunu göstermektedir. Özellikle de, zaman içinde ortaya çıkan gereksinmeleri karşılamak için değer önceliklerinde değişiklikler olmaktadır (Kuşdil ve Kağıtçıbaşı, 2000).

Araştırmada erkek öğretmen adaylarının "Hazcılık" değerine, bayan öğretmen adaylardan daha fazla önem verdikleri görülmektedir. Alanyazında bu araştırma bulgusunu destekleyen çalışmalar bulunmaktadır (Başçiftçi, Yanpınar ve Ergül, 2011; Dilmaç, Deniz ve Deniz, 2009; Sarı, 2005; Sağnak, 2003). Bu sonuç bize, okullarda erkek öğretmenlerin bayan ögretmenlere göre daha fazla bireysel zevk ve istekleri ön plânda olan neşeli, yaşamdan zevk alan, kendini şımartan kişiler olduğunu düşündürmektedir. Diğer bir ifade ile erkek öğretmen adaylarının hayattan alınan zevke ve kişisel ödüllendirilmeye önem verdikleri söylenebilir. Erkek öğretmen adaylarının hayatın güzel yanlarını görmeye çalışmaları, çalıştıkları okullarda daha pozitif bir öğretmenlik tutumları göstermelerine, okullarıyla kolayca bütünleşmelerine yardımcı olabilir. Bu bulgu kadın öğretmenler açısından cinsiyet rolleri kavramı ile açıklanabilir. Kadın öğretmenlerin mesleklerinin dışında aile içersinde çocukların yetiştirilmesi, ev işleri gibi sorumluluklarının yanı sıra bağışlayıcı olmak, sadık olmak, itaatkar olmak, kibar olmak, toplumsal düzeni sağlamak, temiz olmak gibi değerleri de taşımaları toplum tarafından kadından beklenilen davranış ve tutumlar içersinde görülmektedir. $\mathrm{Bu}$ durum kadın öğretmenlerin sorumluluklarını arttırmaktadır. Buna bağlı olarak kendi isteklerini ön plânda tutmasını güçleştirmekte ve kendi kişisel ilgilerini geliştirmeyi 
motive eden hazcılık değerini öncelikli bir değer olarak algılamasını güçleştirmektedir (Schwartz, 1994). Bu bakış açısı, Uysal'ın (2007) ifade ettiği geleneksel statü ve rol yaklaşımı altında yer almaktadır. Temel ve Aksoy'a (2001) göre de Türk kültüründe kadınlara ilişkin özellikler daha çok kişilerarası ilişkilerle ifade edilir. Kadınlardan beklenen temel görevler; duygusal olmaları, işbirliği yapmaları, bakım ve ilgi göstermeleridir. Erkeklerin ise bağımsız davranmaları, aileyi temsil etmeleri, rekabetçi olmaları vurgulanmaktadır.

Kız öğrencilerin öğretmenlik mesleğine yönelik tutum puanları erkek öğrencilerin tutum puanlarından yüksek bulunmuştur. Bu bulgu, k1z öğrencilerin erkek öğrencilere göre öğretmenlik mesleğine yönelik daha olumlu tutuma sahip olduklarını göstermektedir. Alanyazın da bu bulguyu destekleyen çalışmalar bulunmakla (Camadan ve Duysak, 2010; Akpınar, Kaya ve Büyükkasap, 2005; Şen, 2006; Çetinkaya, 2007; Özgür, 1994; Saracaloglu, 1992) birlikte Çapa ve Çil (2000), Çakır, Kan ve Sünbül (2006) ve Semerci ve Semerci (2004) tarafından yapılan araştırmalarda ise öğretmen adaylarının öğretmenlik mesleğine yönelik tutumları cinsiyete göre farklılık göstermediği yönündedir. Araştırmadan elde edilen sonuca göre, kız öğrencilerin erkek öğrencilere nazaran öğretmenlik mesleğine karşı daha 1lımlı baktıkları, nispeten daha fazla değer verdikleri, kendileri için ideal gördükleri ve öğretmen olma isteğinin daha yüksek olması onların öğretmenliğe yönelik tutumlarının daha olumlu olmasını sağlayabilir. Aynı zamanda toplumumuzda "öğretmenlik bayan mesleğidir” algısının kız öğrenciler üzerinde daha etkili olduğu düşünülmektedir. 
Güvenlik, geleneksellik ve güç alt boyutlarının öğretmenlik mesleğine yönelik tutum üzerinde önemli (anlamlı) bir yordayıcı olduğu görülmektedir (Bkz. Tablo. 5). Eğitim fakültesinde okuyan öğretmen adaylarının güvenlik, geleneksellik ve güç değerlerinin öğretmenlik mesleğine yönelik tutumlarını etkilemektedir. Alanyazında ise araştırma bulgularını destekleyecek bir araştırmaya rastlanmamıştır. $\mathrm{Bu}$ üç değerden güvenlik ve geleneksel değerler birbirleri ile uyumluluk gösteren değerlerdir. Bu değerler, benliğin sınırlanmasını, gelenek ve uygulamaların sürdürülmesini, varolan durumun korunmasını vurgulamaktadır (Schwartz, 1994). Bu bağlamda öğretmenlerin devlete hizmet etme boyutuyla siyasal güce bağlı olmaları, kendilerini daha güvende hissetmelerine neden olabilir. Aynı zamanda devlet memuru olmanın iş, sosyal haklar ve işten çıkartılmama gibi güvencelerin öğretmenlerin öğretmenlik mesleğine yönelik tutumlarını şekillendirdiği söylenebilir. Bununla birlikte öğretmen adaylarının geleneksel kültüre ya da dine ait olan geleneklere ve düşüncelere saygı duymak, kabul etmek bağlanmak şeklinde tutum ve davranış geliştirdikleri de söylenebilir. Durmuş (1996) da bireysel tutum ve davranışların büyük ölçüde ahlakî-dinî değerlerle, örf ve adetlerin içerdiği değerlerin etkisi altında kaldığını belirtmektedir. Bu bağlamda öğretmen adaylarının dinî, millî ve ahlakî değerlere önem verdiklerini söyleyebiliriz. Öğretmen adaylarının güvenlik ve geleneksel değerleri, onların öğretmenlik mesleğine yönelik tutumlarında muhafazakâr düşünce ve davranışlar içerisinde olabileceklerini düşündürmektedir.

Araştırmada yer alan öğretmen adaylarının mesleğe yönelik tu- 
tumlarını açıklayan bir başka değerin ise güç olduğunu görmekteyiz. $\mathrm{Bu}$ değer güvenlik ve geleneksellik değerleri ile karşıt veya benzer gruplarda olmamakla beraber koruyucu (muhafazakâr) yaklaşım boyutu altında değerlendirebilinir. Güç değeri, insanlar ve kaynaklar üzerinde kontrol, otorite sahibi olma, zengin olma, sosyal saygınlık sağlama, toplumdaki imajı koruyabilme gibi alt değerlerden oluşmaktadır (Schwartz, 1994). Öğretmen adaylarının bu değer doğrultusunda “otokratik lider” tutumu sergileyecek davranış ve düşünceler gösterebileceği düşünülmektedir. Bu bağlamda, X Kuramında ifade edilen, “otokratik liderlik”te, öğrencilerin rollerini oynamasında baskın olan güdünün korku olduğu, kararlara öğrencilerin katılamadığg, öğretmenin buyurgan öğrencilerin ise buyrulanları yapan olduğu ifade edilmektedir. $\mathrm{Bu}$ tutum ise öğrencilerin okula bağlanmasını ve okulla bütünleşmelerini zorlaştırmaktadır (Başaran, 1992). Aynı zamanda öğretmen adaylarının sınıf yönetimi, öğretmen öğrenci ilişkilerinin nasıl oluşturulacağı konusunda kendilerine olan güvenin ve deneyimin az olması nedeniyle kişi veya durumları kontrol altında tutabilmek için güç değerini öğretmenlik mesleğine yönelik tutumları belirlemede etkili bir değer olarak algıladıkları söylenebilir.

Yapılan bu araştırma doğrultusunda Türkiye'nin içinde bulunduğu sosyo-kültürel ve ekonomik değişim sürecinde öğretmen adaylarının bireysel değer tercihleri içersinde güvenlik, geleneksellik ve güç değerlerinin önemli olduğu görülmektedir. Öğretmen adaylarının değer tercihlerinin veya algılarının zenginleştirilmesi ve bu konuda farkındalığın arttırılması yönünde çalışmalar onların öğretmenlik mesleğine 
yönelik olumlu tutumlarını zenginleştireceğini düşündürmektedir. $\mathrm{Bu}$ bağlamda eğitim fakültelerinde değer, değerin önemi, değerlerin kazandırılması ve değer tercihleri konuları ile ilgili seçmeli dersler oluşturulabilir. Aynı zamanda değerlerin pedagojik formasyon kapsamındaki rehberlik, sınıf yönetimi derslerinin içeriğinde yer alması düşünülebilinir. Ayrıca yüksek lisans ve doktora programlarında da duyuşsal alan dersi içinde yer alabilir. Lisans ve yüksek lisans düzeylerinde değerlerin, aktif, deneysel ve somut problem çözümlerine dayalı olarak aktarılması gençlerin değer geliştirmelerine yardımcı olabileceği gibi, onların öğretmenlik mesleğine yönelik istendik tutumlar geliştirmelerine de katkı sağlayabilir.

Ayrıca değerlerin ihtiyaca göre değişebilme özelliği dikkate alındığında değerlerle ilgili yapılacak boylamsal araştırmalardan elde edilen bulguların öğretmen tutumlarını belirleyen temel değerlerin oluşturulmasına katkı sağlayacağı düşünülmektedir. Ayrıca değer tercihleri ve öğretmen tutumlarına yönelik daha geniş çaplı araştırmalara ihtiyaç vardır.

\section{Kaynakça}

Akkiprik, G. B. (2007). Genel lise ögretmenlerine göre karakter ĕgitimi yoluyla öğrencilere kazandırılacak değerler: Çok boyutlu bir araştırma. Yayınlanmamış yüksek lisans tezi, Yeditepe Üniversitesi, Eğitim Bilimleri Enstitüsü.

Aktepe, V. ve Yel, S. (2009). İlköğretim öğretmenlerinin değer yarg1larının betimlenmesi. Kırşehir ili örneği. Türk Ĕ̆itim Bilimleri Dergisi, 7(3), 607-622. 
Alnıaçı, Ü. ve Yılmaz, C. (30 Ekim-1 Kasım 2008). Değer yargıları ve tüketimde çevreci eğilimler. 13. Ulusal Pazarlama Kongresi, Çukurova Üniversitesi, Adana.

Aydın, M. (2003). Gençliğin değer algısı: Konya örneği. Değerler Ĕ̈itimi Dergisi,1(3), 121-144.

Başaran, İ. E. (1994). Eğitim yönetimi. Ankara: Kadığlu Matbaası.

Bursalığlu, Z. (2000). Okul yönetiminde yeni yapı ve davranış. Ankara: Pegem A.

Çapa, Y. ve Çil, N. (2000). Öğretmen adaylarının öğretmenlik mesleğine yönelik tutumlarının farklı değişkenler açısından incelenmesi. Hacettepe Üniversitesi Ĕ̌itim Fakültesi Dergisi, 18, 69-73.

Çetinkaya, R. (2007). Türkçe öğretmeni adaylarının yeterlilik algıları ve ögretmenlik mesleğine yönelik tutumları. Yayımlanmamış yüksek lisans tezi, Selçuk Üniversitesi Sosyal Bilgiler Enstitüsü.

Dilmaç, B., Deniz, M. ve Deniz, M. E. (2009). Üniversite öğrencilerinin öz-anlayışları ile değer tercihlerinin incelenmesi. Değerler Ĕ̈itimi Dergisi, 7(18), 9-24.

Durmuş, Ç. (1996). Değerlerin meslek grupları açısından incelenmesi. Yayınlanmamış yüksek lisans tezi, Marmara Üniversitesi Sosyal Bilimler Enstitüsü.

Erdem, A. R., Gezer, K. ve Çokadar, H. (28-30 Eylül 2005). Ortaöğretim fen-matematik ve sosyal alanlar öğretmenliği tezsiz yüksek lisans öğrencilerinin öğretmenlik mesleğine ilişkin tutumları. XIV. ulusal eğitim bilimleri kongresi kongre kitabı I.cilt içinde (471-477), Denizli.

Fırat, N. Ş. (2010). Okul müdürü ve öğretmenlerin okul kültürü ile değer sistemlerine ilişkin algıları. Principals' and teachers' per- 
ceptions about school culture and value systems. Eğitim ve Bilim. 35(156), 71-83.

Fraenkel J. R. ve Wallen N. E. (1993). How to design and evaluate research in education, NewYork, NY: McGraw-Hill.

Dursunoğlu, H. (2003). Cumhuriyet döneminde ilköğretime öğretmen yetiştirmenin tarihi gelişimi. Milli Eğitim Dergisi, 160, 64-74.

Gözütok, F. D., Akgün, Ö. E. ve Karacaoğlu, Ö. C. (2005). İlköğretim programlarının öğretmen yeterlilikleri açısından değerlendirilmesi. Ĕ̆itimde yansımalar: VIII Yeni ilkögretim programlarını değerlendirme sempozyumu bildiriler kitabı içinde (17-40). Ankara: Sim Matbaası.

Güngör, E. (2000). Değerler psikolojisi üzerine araştırmalar. İstanbul: Ötüken Yayınları.

Güngör, E. (1998). Değerler psikolojisi üzerinde araştırmalar. İstanbul: Ötüken Yayınları.

Güvenç, B. (1976). Değerler, tutumlar ve davranışlar. Ankara: Türkiye Ortadoğu Amme İdaresi Enstitüsü Yayınları.

İşcan, C. D. ve Senemoğlu, N. (2009). İlköğretim 4. sınıf düzeyinde değerler eğitim programının etkililiği. Eğitim ve Bilim, 34(153), 1-14.

Kaya, A. ve Büyükkasap, E. (2005). Fizik öğretmenliği programı öğrencilerinin profilleri, ögretmenlik mesleğine yönelik tutum ve endişeleri: Erzurum örneği. Kastamonu Ĕ̆itim Dergisi, 13(2), 367-380.

Kuşdil, M. E. ve Kağıtçıbaşı, Ç. (2000). Türk öğretmenlerin değerler yönelimi ve Schwartz değer kuramı. Türk Psikoloji Dergisi, 15(45), 59-76. 
Mehmedoğlu, A. U. ( 26-28 Kasım 2007).Üniversite öğrencilerini değer yönelimleri ve dindarlık. Değerler ve Eğitimi Uluslararası Sempozyumu. İstanbul.

Memişoğlu, S. P. (2006). Nasıl bir öğretmen. Orta öğretimde yeniden yapılanma sempozyumu 20-22 Aralık 2004 bildiriler kitabı içinde (334-338). Ankara: MEB Talim Terbiye Kurulu Başkanlığı.

Rokeach, M. (1973). Nature of human values. New York: The Free Press.

Oktay, A. (1991). Öğretmenlik mesleği ve öğretmenin nitelikleri. Marmara Üniversitesi Atatürk Ĕ̆itim Fakültesi Eğitim Bilimleri Dergisi, 3, 187-193.

Özkul, A. S. (2007). Yaşam ve çalışma değerlerini etkileyen faktörler, Süleyman Demirel Üniversitesi öğrencileri üzerine bir çalışma. Yayınlanmamış yüksek lisans tezi, Süleyman Demirel Üniversitesi Sosyal Bilimler Enstitüsü.

Özgür, F. N. (1994). Öğretmenlik mesleğine karşı tutum. Yayınlanmamış doktora tezi, Marmara Üniversitesi Sosyal Bilimler Enstitüsü.

Ünal, S., Deniz, A. ve Can, P. (2008). Marka bağlılığı ve kişisel değerler açısından pazar bölümleme. Íktisadi ve Ídari Bilimler Dergisi, 22(1), 211-237.

Sağnak, M. (2003). İlköğretim okullarında görevli yönetici ve öğretmenlerin örgütsel değerlere ilişkin algllart ile bireysel değerleri arasındaki uyum düzeyi. Yayımlanmamış doktora tezi, Abant İzzet Baysal Üniversitesi Eğitim Bilimleri Enstitüsü.

Sarı, E. (2005). Öğretmen adaylarının değer tercihleri: Giresun eğitim fakültesi örneği. Değerler Ĕ̆itimi Dergisi, 3(10), 73-88. 
Semerci, N. ve Semerci, Ç. (2004). Türkiye'de öğretmenlik tutumları. Firat University Journal of Social Science 14(1), 137-146.

Sezgin, F. (2006). Illkögretim okulu ögrretmelerinin bireysel ve örgütsel değerlerinin uyumu. Yayımlanmamış doktora tezi, Gazi Üniversitesi Eğitim Bilimleri Enstitüsü.

Şen, B. (2006). Sinıf öğretmeni adaylarının öğretmenlik tutumlart ile ögrenme ve ders çalışma stratejileri arasındaki ilişki. Yayımlanmamış yüksek lisans tezi, Marmara Üniversitesi Eğitim Bilimleri Enstitüsü.

Şenel, H. G., Demir, İ., Sertelin, Ç., Kılıçaslan, A. ve Köksal, A. (2004). Öğretmenlik mesleğine yönelik tutum ve kişilik özellikleri arasındaki ilişki. Eğitim Araştırmaları, 15, 99-109.

Taşdan, M. (2010). Türkiye'deki resmi ve özel ilköğretim okulu öğretmenlerinin bireysel değerleri ile okulun örgütsel değerleri arasındaki uyum düzeyi. Kuram ve Uygulamada Eğitim Yönetimi 16(1), 113-148.

Taşdemir, M. (1996). Dört yıllık sınıf öğretmeni yetiştirme programının değerlendirilmesi. Çă̆daş Ĕ̈itim, 225, 24-27.

Terzi, A. R. ve Tezci E. (2007). Necatibey Eğitim Fakültesi öğrencilerinin öğretmenlik mesleğine ilişkin tutumları. Kuram ve Uygulamada Ĕ̈itim Yönetimi, 52, 593-614.

Uysal, V. (2007). Yetişkinlerde dindarlık ve değerler: dini hayat, dĕger tercihleri ve kadına bakış eğilimleri. Değerler ve Eğitimi Uluslararası Sempozyumu, İstanbul.

Üstüner, M. (2004). Geçmişten günümüze Türk eğitim sisteminde öğretmen yetiştirme ve günümüz sorunları. İnönü Üniversitesi Ĕ̈itim Fakültesi Dergisi, 5(7), 63-82. 
Yaşar, Ş., Gültekin, M., Türkan, B., Yıldı, N. ve Girmen, P. (14-16 Kasım 2005). Yeni ilköğretim programlarının uygulanmasına ilişkin sınıf ögrretmenlerinin hazırbulunuşluk düzeylerinin ve eğitim gereksinimlerinin belirlenmesi. Yeni İlköğretim Programlarını Değerlendirme Sempozyumu, Eskişehir.

Yiğittir, S. ve Öcal, A. (2010). Öğretmenlerin öğrencilerine kazandırmak istedikleri değerlere yönelik bir inceleme. Ĕgitim ve Insani Bilimler Dergisi: Teori ve Uygulama. Journal of Education and Humanities: $\quad$ Theory and Practice, 2(4), 3-24.

Yıldız, S., Taşkıran, E. ve Çiçe, M. (5-7 Mayıs 2011). Üniversite ögrencilerinin bireysel değerleri ile girişimcilik ĕgilimleri arasındaki ilişki. Kafkas Üniversitesi’nde bir araştırma. 10. Ulusal İşletmecilik Kongresi, İzmir. 